\title{
Rectovaginal Septum Nodule: The Key for an Unexpected Diagnosis
}

\author{
Marco Silva ${ }^{a}$ Pedro Moutinho-Ribeiro ${ }^{a}$ Vítor Magno-Pereira ${ }^{b}$ \\ Filipe Vilas-Boas $^{\mathrm{a}}$ Guilherme Macedo ${ }^{\mathrm{a}}$ \\ a Department of Gastroenterology, Centro Hospitalar de São João, Porto Medical School, Porto, Portugal; \\ ${ }^{\text {b}}$ Department of Gastroenterology, Centro Hospitalar do Funchal, Funchal, Portugal
}

\section{Keywords}

Anal cancer - Metastasis - Endoscopic ultrasound-guided fine-needle aspiration

\section{Nódulo do Septo Rectovaginal: A Chave para um Diagnóstico Inesperado}

\section{Palavaras Chave}

Cancro anal · Metástase · Aspiração por agulha fina ultrassonográfica

We report the case of a 54-year-old female with a 2-year history of hypertrophic cranial pachymeningitis (medicated with prednisolone $5 \mathrm{mg}$ and pregabalin), a cranioencephalic traumatic accident in childhood (with a period in coma), and no other relevant medical history including immunosuppressive pathology as HIV. A Gallium-67 scintigraphy was performed for etiological evaluation, which revealed a vaginal uptake. With the exception of neurological symptoms, she had no other complaints and denied all risk factors for anal cancer. On digital rectal examination, a smooth, irregular nodule measuring $15 \mathrm{~mm}$ was palpated. An endovaginal ultrasonography revealed a

\section{KARGER}

E-Mail karger@karger.com www.karger.com/pjg
(C) 2018 Sociedade Portuguesa de Gastrenterologia Published by S. Karger AG, Basel

Karger

Upen access

This article is licensed under the Creative Commons AttributionNonCommercial-NoDerivatives 4.0 International License (CC BYNC-ND) (http://www.karger.com/Services/OpenAccessLicense) Usage and distribution for commercial purposes as well as any distribution of modified material requires written permission. solid mass of the rectovaginal septum in close contact with the anterior wall of the rectum, suggesting the possibility of a nodule of endometriosis. Flexible rectosigmoidoscopy was then performed and a bulging of the lower rectal wall covered by normal mucosa $15 \mathrm{~mm}$ in diameter was found, corresponding to the described lesion. Furthermore, during the retroflexion maneuver for complete observation of the distal rectum and anal canal, an irregular sessile polypoid lesion was found, extending from the anal verge (Fig. 1). Biopsies were taken and were consistent with a squamous cell anal carcinoma. Radial endoscopic ultrasound (EUS) was first performed to evaluate the extraluminal nodule. It corresponded to a rounded, homogenous, hypoechogenic lesion, with regular contours and well-defined borders, located in the recto-vaginal septum (extrinsic to the rectal wall) (Fig. 2, 3). No perilesional lymph nodes were detected. EUS fine-needle aspiration (22-G needle) through linear EUS was then performed and the cytological diagnosis was a metastasis of the squamous cell anal carcinoma.

The patient was discussed in a multidisciplinary oncological meeting and proposed for radiochemotherapy. Follow-up at 3 months revealed a good tolerance except for limited oral mucositis, pending radiological evaluation of therapy response. 


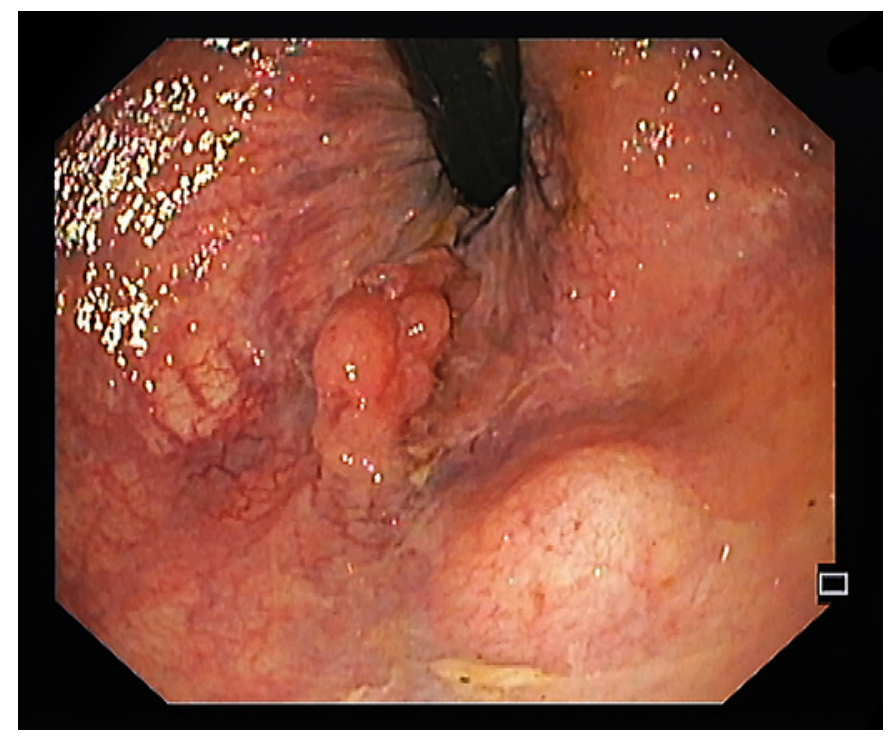

Fig. 1. Rectosigmoidoscopy imaging showing an irregular polypoid sessile lesion, extending from the anal verge and a bulging of the anterior rectal wall.

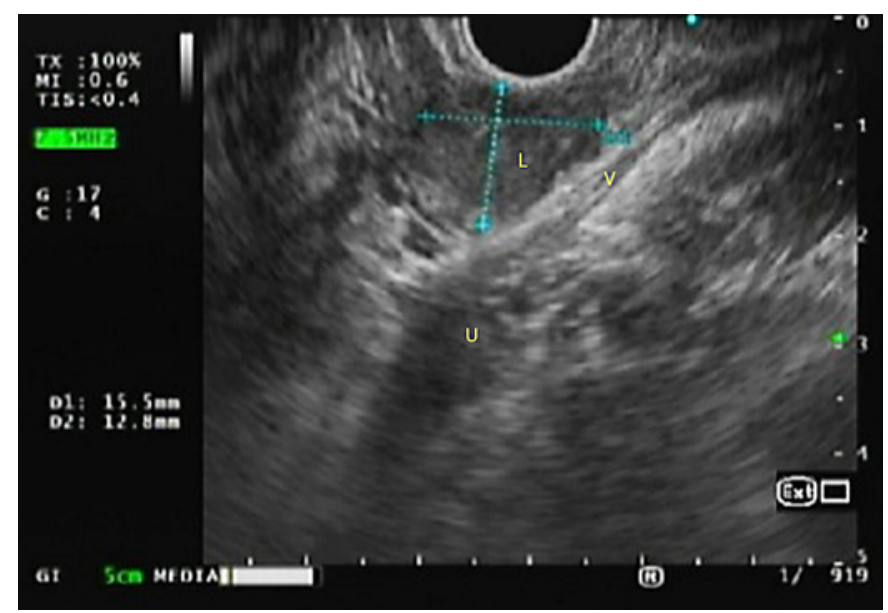

Fig. 2. Linear endoscopic ultrasonography imaging at $6 \mathrm{~h}$ showing a well-defined homogenous hypoechogenic lesion with irregular contours and well-defined limits, with an approximate size of 16 per $13 \mathrm{~mm}$ of greater axis. L, lesion; V, vagina; $\mathrm{U}$, uterus.

Extensive evaluation including brain magnetic resonance imaging excluded signs of carcinomatous meningitis. The final diagnosis was metastatic squamous cell anal carcinoma and idiopathic hypertrophic cranial pachymeningitis cortico-responsive of probable fibrocicatricial nature. In fact, to date, there have been no other reports of an association of these two diagnoses.

Rectovaginal Septum Nodule

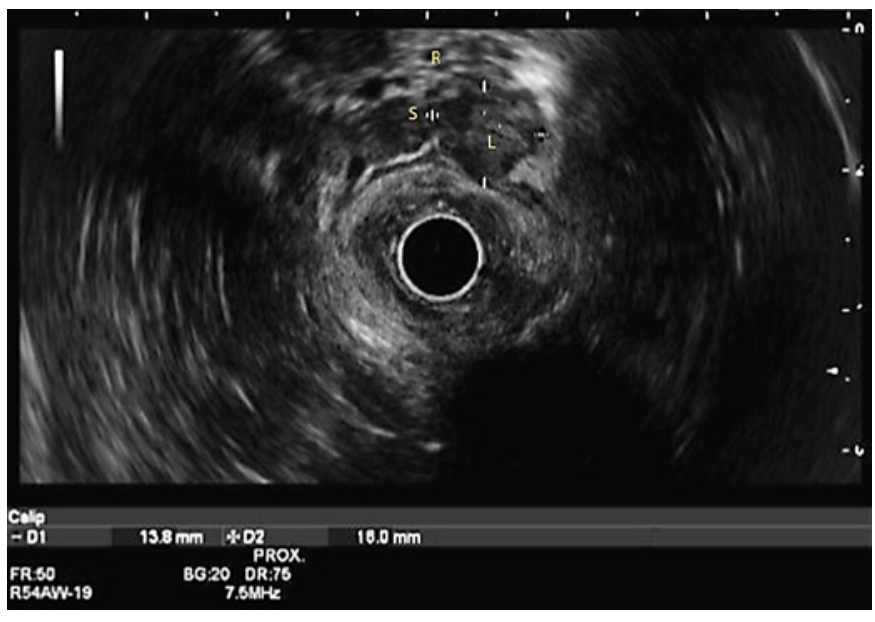

Fig. 3. Radial endoscopic ultrasonography imaging at $1 \mathrm{~h}$ showing the homogenous hypoechogenic lesion previously characterized located in the recto-vaginal septum (extrinsic to the wall of the rectum), although without a clear cleavage plane with the rectum muscular layer. L, lesion: R, rectum; S, recto-vaginal septum.

Squamous cell carcinoma of the anus is a relatively rare malignancy, accounting for less than $2 \%$ of gastrointestinal cancers [1]. The median age of diagnosis is 60 years and there is a slightly higher incidence in women [2]. However, its incidence has been increasing, especially in certain populations with high-risk behavior and in those with HIV [3]. Metastatic presentation accounts for only $10-20 \%$ of cases, and patients usually have a poor prognosis, with 5-year median overall survival rates of $10 \%$ in men and $20 \%$ in women $[3,4]$. A high index of suspicion and knowledge of the relevant anatomy and pathophysiology are essential to avoid misdiagnosis and provide proper management.

On the other hand, cancer of the recto-vaginal septum is an extremely rare entity and in most cases it is associated with endometriosis foci [5]. In the literature, only 2 cases of fallopian tube cancer in this location have been reported [5]. To the best of our knowledge, this is the first report of a metastatic spread of squamous cell anal carcinoma to the recto-vaginal septum.

\section{Statement of Ethics}

All rules of the local ethics committee ("Comissão de Ética para a Saúde do Centro Hospitalar São João/Faculdade de Medicina da Universidade do Porto") were followed, preserving patient identity and confidentiality. 


\section{Disclosure Statement}

The authors declare that they have no conflict of interest.

\section{Funding Sources}

The authors declare that there was no source of founding.

\section{Author Contributions}

M.S.: responsible for the collection and interpretation data and drafting of the manuscript. P.M.-R.: performed endoscopic ultrasonography; critical revision of the manuscript. V.M.-R.: responsible for the data collection and drafting of the manuscript. F.V.-B.: performed endoscopic ultrasonography and rectosigmoidoscopy; critical revision of the manuscript. G.M.: critical revision of the manuscript, final approval of the paper.
References
1 Elorza G, Saralegui Y, Enríquez-Navascués Jm, Placer C, Velaz L: Anal intraepitelial neoplasia: a narrative review. Rev Esp Enferm Dig 2016;108:31-39.

2 Osborne MC, Maykel J, Steele SR: Anal squamous cell carcinoma: an evolution in disease and management. World J Gastroenterol 2014;20:13052-13059.

3 Dewdney A, Rao S: Metastatic squamous cell carcinoma of the anus: time for a shift in the treatment paradigm? ISRN Oncol 2012;2012: 756591.
4 Glynne-Jones R, Nilsson Pj, Aschele C, Goh V, Peiffert D, Cervantes A, et al: Anal cancer: ESMO-ESSO-ESTRO clinical practice guidelines for diagnosis, treatment and follow-up. Eur J Surg Oncol 2014;40:1165-1176.

5 Lopez N, Grabowski J, De Santiago J, Zapardiel I: Carcinoma of the recto-vaginal septum. comprehensive literature review. J Obstet Gynaecol 2016;36:450-454. 